\title{
VALUASI EKONOMI SUMBERDAYA DANAU TEMPE, KABUPATEN WAJO, PROPINSI SULAWESI SELATAN: NILAI BUKAN MANFAAT
}

\author{
Irwan Muliawan ${ }^{1}$ dan Fatriyandi Nur Priyatna ${ }^{1}$
}

\begin{abstract}
ABSTRAK
Kebijakan pengelolaan terhadap suatu sumberdaya di era ini setidaknya telah memasukkan tiga unsur sebagai pertimbangan dasar. Ketiga unsur tersebut adalah ekonomi, sosial dan lingkungan. Pertimbangan ekonomi, menitikberatkan pada paradigma benefit yang dapat diperoleh dari kegiatan ekstraksi. Sumberdaya perikanan adalah sumberdaya yang renewable atau terbaharukan. Kebijakan pengelolaan seharusnya mempertimbangkan nilai keberadaan sumberdaya dan nilai warisan sumberdaya tersebut demi kebutuhan masa depan. Tulisan ini berupaya mengungkap bahwa nilai bukan manfaat (nilai keberadaan dan nilai warisan) sebagai nilai berdasarkan penghargaan masyarakat terhadap sumberdaya perikanan yang dapat memberikan pandangan tersendiri dalam kebijakan pengelolaan sumberdaya. Untuk itu, teknik Contingent Valuation Method (CVM), digunakan sebagai dasar untuk menghitung nilai bukan manfaat (Non-Use Value) tersebut. Hasil penelitian menunjukan bahwa Nilai Bukan Manfaat Danau Tempe adalah Rp.1.962.621.327 dan terdapat kecenderungan bahwa masyarakat memanfaatkan sumberdaya secara maksimal tanpa memperhatikan nilai keberadaan sumberdaya danau. Masyarakat di sekitar Danau Tempe sangat berharap kelestarian sumberdaya danau dapat dipertahankan demi kepentingan anak cucu di masa mendatang.
\end{abstract}

Kata Kunci $\quad$ : Nilai Bukan Manfaat, Contingent Valuation Method, Danau Tempe.

\section{Abstract : Economic Valution of Tempe Lake Resource, Wajo District, of South Sulawesi Province: by Irwan Muliawan and Fatriyandi Nur Priyatna}

Recently, policy in resource management has three important elements as basis for considerations. The elements are economic, social and environment. Specifically for economic consideration, it is focused on the benefit which can be abtained from extraction activities. Fisheries resource is a renewable resource. Policy on managing the resource should consider the existence value and heritage value of he resource. This article attempts to express the non-use value (existence value and bequest value) as value of pursuant to socialy appreciation to fishery resource in Lake Tempe, Wajo Regency, South Sulawesi is able to reflect its view in policy of resource management. A contingent Valuation Method (CMV) was used to estimate the non use value. Results show that the Lake Tempe non use value were Rp. 1962.621.327 it is also indicate that society tends to explot the resources maximally regardless of value of exitance of lake resource. People around Lake Tempe expeet that sustainability of lake resource has to be maintaimed for future importance.

\section{Keyword : Non Use Value, Contingent Valuation Method, Tempe Lake}

\section{PENDAHULUAN}

Pembangunan dalam berbagai hal, dewasa ini telah mempertimbangkan masuknya tiga faktor utama sebagai bagian dari orientasi pembangunan. Ketiga faktor tersebut yakni, ekonomi, sosial dan lingkungan. Faktor ekonomi secara umum memberi pandangan "untung rugi" dari program/kegiatan yang dilakukan. Faktor sosial menyangkut acceptability dan tolerability dari kelompok masyarakat yang merupakan stakeholder. Terakhir faktor lingkungan, yang akhir-akhir ini mendapatkan sorotan karena akibat perubahan lingkungan dari tahun ketahun telah mengakibatkan

\footnotetext{
${ }^{1}$ Peneliti pada Balai Besar Riset Sosial Ekonomi Kelautan dan Perikanan

JI. KS. Tubun Petamburan VI, Jakarta 10260

Telp. $02153650162 /$ Fax. 02153650159
} 
degradatif lingkungan semakin tinggi sehingga berdampak negatif terhadap fungsi ekologisnya.

Sebagai bagian dari pertimbangan dalam kebijakan pembangunan, pandangan komprehensif dan holistik dalam pengelolaan sumberdaya, setidaknya tersirat dalam wacana berikut: pertama, proporsi ketiga faktor di atas sebaiknya dirancang seimbang menyesuaikan tujuan yang hendak dicapai. Hal ini berarti, secara kuantitas dan kualitas, masing-masing faktor tersebut terwakili dalam kegiatan pembangunan dengan besaran nilai proporsional sesuai tujuan yang direncanakan. Kedua, ketiga faktor tersebut haruslah didasari oleh landasan tertentu, baik itu landasan hukum, hasil kajian ilmiah, maupun perilaku/pengalaman tertentu ataupun kejadian alam terkait sumberdaya yang dikelola.

Tulisan ini mencakup tentang perubahan cara pandang yang menjadi dasar-dasar dalam menyusun orientasi pembangunan. Faktor ekonomi terkait erat dengan persepsi dan penilaian masyarakat terhadap kondisi lingkungan. Keterkaitan ini merupakan salah satu pendekatan untuk menilai kondisi lingkungan. Titik berat penilaian pada paradigma ekonomi dalam pengelolaan lingkungan, umumnya ditujukan atas ketersediaan manfaat yang dapat diperoleh dari pemanfaatan sumberdaya. Namun, lingkungan itu sendiri memiliki nilai tidak hanya sebagai sumberdaya yang diekstraksi secara langsung, tetapi juga memiliki nilai ekonomi berupa potensi yang terkandung juga faktor yang diwariskan. Potensi tersebut berupa keberadaan serta kemampuan lingkungan menyediakan sumberdaya, maupun sebagai sumberdaya yang harus disisihkan demi keberlanjutan atau pewarisan untuk dimanfaatkan di masa mendatang.

Secara teknis, penilaian ekonomi terhadap kualitas lingkungan juga berkembang, termasuk juga terkait nilai bukan manfaat atas sumberdaya (nilai keberadaan dan nilai warisan). Untuk itu, ahli ekonomi sumberdaya melakukan upaya untuk menilai sumberdaya berdasarkan preferensi manusia terhadap sumberdaya, atau yang dikenal sebagai teknik Contingent Valuation Method (CVM) (FAO, 2000). CVM pertama kali diajukan oleh Davis (1963 dalam Dosi, 2000), dan telah digunakan secara luas dalam pengambilan keputusan terhadap evaluasi program terkait dengan perubahan lingkungan. Pendekatan CVM pada hakekatnya bertujuan mengetahui keinginan membayar (Willingness to Pay atau WTP) dari sekelompok masyarakat, misalnya terhadap perbaikan kualitas lingkungan atau atas potensi sumberdaya untuk dimanfaatkan. Hal ini senada dengan FAO (2000), yang menyatakan bahwa tujuan dari Contingent Valuation dapat mengukur variasi nilai kompensasi dan nilai persamaan suatu barang yang ditanyakan. Variasi nilai kompensasi dan nilai persamaan tersebut diperoleh dengan bertanya kepada seseorang yang memiliki keterkaitan erat terhadap sumberdaya yang dinilai untuk memberikan nilai moneter yang ingin dibayarkannya.

Tujuan penelitian ini adalah mengetahui total nilai bukan manfaat dari sumberdaya Danau Tempe di Kabupaten Wajo Sulawesi Selatan, sebagai langkah dalam pengelolaan sumberdaya danau. Hal ini sangat penting, mengingat kondisi lingkungan dan sumberdaya perairan danau yang terus semakin menurun. Salah satu indikasinya ditunjukkan dengan penurunan kualitas airnya. Sementara perubahan lingkungan tersebut tidak terlepas dari interaksi kegiatan ekonomi masyarakat di sekitarnya. Tindakan ekonomi yang dilakukan oleh masyarakat tidak terlepas juga dari persepsi masyarakat tersebut terhadap sumberdaya. Dampak akhirnya di sektor perikanan berupa menurunnya produktivitas hasil tangkapan. Sehingga, nilai bukan manfaat perlu diketahui besarannya, mengingat nilai ini terkait erat dengan persepsi masyarakat terhadap keberadaan dan keberlangsungan sumberdaya. 


\section{METODOLOGI}

\subsection{Waktu, Lokasi dan Gambaran Umum Penelitian}

Penelitian ini berlokasi di Danau Tempe, Kabupaten Wajo, Sulawesi Selatan. Tahap pengumpulan data tersebut dilaksanakan pada bulan Agustus 2007. Secara umum, tahapan penelitian ini sebagai berikut:(Adrianto, 2007)

Tahap1.

1. Mengidentifikasi target populasi/responden.

2. Menentukan target kelompok populasi/responden,

3. Mengidentifikasi apakah target populasi/responden homogen atau heterogen.

Tahap 2.

1. Mendisain kuesioner.

2. Menyesuaikan kuesioner dengan tujuan survei.

3. Menyesuaikan kuesioner dengan beberapa pertimbangan (kesediaan waktu, tenaga dan pendanaan).

\section{Tahap 3.}

1. Tabulasi dan analisis data deskriptif hasil survei.

2. Tabulasi data sesuai dengan parameter penting yang telah ditetapkan.

3. Melakukan analisis deskriptif terhadap parameter penting yang telah ditetapkan

Tahap 4.

1. Menghitung Willingness to Pay (WTP) hasil survei.

2. Membangkitkan model regresi WTP.

3. Mengestimasi WTA.

4. Apabila diperlukan dilakukan analisis sensitivitas

Tahap 5.

1. Penyusunan laporan survei

2. Penyajian hasil survei.

3. Pelaporan hasil survei

\subsection{Teknik Pengumpulan data}

Pengumpulan data dilakukan menggunakan kuesioner, yaitu terkait dengan data-data berupa: WTP, pendapatan, lama pendidikan, usia dan pengalaman. Secara teknis, pengumpulan data yang digunakan menggunakan teknik permainan pilihan (trade-off games), yaitu responden yang mewakili nelayan diminta untuk menentukan beberapa pilihan nilai dan skenario yang ditentukan oleh valuator/enumerator. Sementara aktivitas sosial ekonomi masyarakat dikumpulkan dengan wawancara menggunakan kuesioner yang telah disesuaikan dengan tujuan penelitian.

\subsection{Metode Analisis Data}

Metode untuk menilai atas nilai bukan manfaat sumberdaya (Non-Use Value menggunakan teknik Contingent Valution Method (CVM). Selama terjadi informasi pasar, maka sumber penilaian yang dianggap paling baik atau paling kuat adalah nilai pasar. Nilai pasar adalah harga barang dan jasa yang ditetapkan oleh penjual dan pembeli tanpa intervensi pihak lain atau dalam keadaan kompetisi sempurna (Davis and Johnson, 1987). Jika data yang berorientasi pada nilai pasar (market) tidak ada maka, valuasi membutuhkan teknik bukan pasar(nonmarket) untuk memperoleh informasi WTP individu. Teknik nonmarket yang sudah umum diketahui seperti, Travel Cost Method, Hedonic Price Method, dan Contingent Valuation Method (Ulibarri, 1997).

Data yang telah dikumpulkan kemudian dipilah dan ditabulasi agar memenuhi keperluan analisis. Analisis data pada Teknik CVM menggunakan perhitungan Total Benefit sebagai analisis dasar untuk menghitung WTP. untuk mendapatkan dugaan hubungan antara WTP (nilai keberadaan ekosistem mangrove) dengan karakteristik responden (pemanfaat mangrove) maka didekati dengan menggunakan formula sebagai berikut:

$$
W T P_{t}=\beta_{0}+\sum_{t=1}^{n} \beta_{t} X_{t}
$$


dimana ;

WTP $=$ Kemampuan membar pengguna terhadap suatu sumberdaya/Willingness to Pay $-i$

$\mathrm{X}_{\mathrm{i}}=$ Parameter penjelas $\mathrm{ke}-\mathrm{i}$ (seperti $\mathrm{P}$ e $\mathrm{n} \mathrm{d}$ a $\mathrm{p}$ a $\mathrm{t}$ a $\mathrm{n}, \mathrm{u} \mathrm{m} \mathrm{u}$, pendidikan/dependent Variable - I (revenue, ages, education) (Grigalunas and Congar, 1995).

Persamaan di atas, dinormalisasikan agar menyesuaikan bentuk data yang telah dikumpulkan. Bentuk data ordinal seperti pengalaman kerja, usia dan tingkat pendidikan kemudian ditransformasi, sehingga mengharuskan digunakan regresi logaritma ganda. Hasil persamaan berdasarkan regresi logaritma berganda dilakukan dengan tingkat kepercayaan 95\% (Yaping, 1999). Adapun bentuk persamaannya ditayangkan sebagai berikut:

$$
\begin{aligned}
& \operatorname{LnWTP}=a+b_{1} \frac{1}{n} \sum_{i=1}^{n} \operatorname{LnA}+b_{2} \frac{1}{n} \sum_{i=1}^{n} \operatorname{LnE}+ \\
& b_{3} \frac{1}{n} \sum_{i=1}^{n} \operatorname{LnXP}+b_{4} \frac{1}{n} \sum_{i=1}^{n} \operatorname{LnI}
\end{aligned}
$$

dimana:

$$
\begin{aligned}
& \text { WTP = Willingness to Pay (Nilai } \\
& \text { Kesediaan Membayar) } \\
& \text { a }=\text { Konstanta } \\
& \mathrm{E} \quad=\text { Tingkat Pendidikan (hasil } \\
& \text { pembobotan) } \\
& \text { I = Pendapatan per tahun } \\
& \text { A = Usia Responden (tahun), } \\
& \mathrm{XP}=\text { Pengalaman, }
\end{aligned}
$$

Penggunaan metoda yang digunakan Grigalunas and Congar, (1995) umumnya digunakan untuk data yang memiliki nilai sebaran yang relatif seragam, dengan interval tidak terlalu besar. Sedangkan untuk memudahkan analisis data untuk data yang memiliki seperti digambarkan tersebut dapat digunakan metoda yang digunakan oleh Yaping, (1999). Tahap terakhir dalam teknik CVM adalah mengagregatkan rataan lelang yang diperoleh pada tahap tiga. Proses ini melibatkan konversi dari data rataan sampel ke rataan populasi secara keseluruhan. Salah satu cara untuk mengkonversi ini adalah dengan mengalikan rataan sampel dengan jumlah rumah tangga di dalam populasi $(\mathrm{N})$.

\section{HASIL DAN PEMBAHASAN}

\subsection{Karakteristik Responden}

Sumberdaya Danau Tempe dimanfaatkan oleh beberapa jenis pemanfaatan yang berbeda dan lintas sektoral. Berdasarkan hasil penelitian, diperoleh informasi bahwa jenis pemanfaatan yang ada pada sumberdaya tersebut berupa perikanan tangkap, pertanian dan transportasi. Perhitungan nilai Willingness to Pay (WTP) diambil dari ketiga pemanfaat tersebut. Tabel 1 menunjukkan nilai rataan dari keseluruhan responden yang diwawancarai.

Usia responden di lokasi penelitian berkisar antara 25 hingga 62 tahun dengan rata-rata usia 40 tahun. Jika dilihat dari faktor pendidikan responden maka diketahui bahwa

Tabel 1. Karakteristik Responden di Danau Tempe, Propinsi Sulawesi Selatan

Table 1. Respondents Characteristic at the Lake Tempe, South Sulawesi Province

\begin{tabular}{clr}
\hline No & \multicolumn{1}{c}{ Uraian/Descriptions } & Rata-Rata/Average \\
\hline 1. & Usia / Ages (tahun/years) & 40 \\
2. & Pendidikan/ Educations (tahun/years) & 6 \\
3. & Pengalaman Usaha / Experiences (tahun/years) & 18 \\
4. & Pendapatan per Tahun/ Incomes per year (Rp/years) & 25.067 .838 \\
\hline
\end{tabular}

Keterangan / notes : $\mathrm{n}: 25$ responden 
umumnya responden memiliki tingkat pendidikan yang rendah yaitu hanya setingkat sekolah dasar saja. Sementara pengalaman usaha responden berkisar antara 2 hingga 40 tahun. Jika diperhatikan dari pendapatan responden per tahun maka diperoleh informasi bahwa pendapatan rata-rata responden sebesar Rp 25.067.838 per tahun dengan waktu berusaha yang tidak penuh selama 12 bulan. Hal ini disebabkan karena kegiatan pemanfaatan sangat bergantung dari tinggi rendahnya muka air dari perairan tersebut (Koeshendrajana, et al., 2007).

\subsection{Nilai Bukan Pemanfaatan Danau Tempe}

Angka untuk Nilai Bukan Manfaat (NBM) yang didapat adalah sebesar Rp.1.962.621.326. Hasil analisis NBM dengan menggunakan teknik CVM sangat dipengaruhi oleh bentuk kuesioner dalam menjaring besaran nilai yang diminta dari responden. Teknik CVM memiliki dua kelemahan; pertama, potensi bias dalam menjaring data, kedua, kesulitan dalam mengidentifikasi responden, khususnya di negara berkembang dimana informasi mengenai jasa-jasa lingkungan sangat terbatas (Winpenny, 1991). Kuesioner untuk menjaring Nilai Keberadaan (NK) digunakan iuran/biaya untuk berpatroli mengawasi penggunaan metode tangkap tidak ramah lingkungan. Sedangkan pada kuesioner untuk menjaring besaran Nilai Pelestarian/Keberlanjutan (NP) sumberdaya diarahkan agar responden memilih bentukbentuk pengorbanan yang diharapkan dapat memberi manfaat untuk kepentingan anak cucu di masa mendatang. Bentuknya seperti membayar iuran, mengurangi wilayah pengoperasian penangkapan ikan, dan opsi lainnya yang disesuaikan dengan fenomena yang terjadi di masyarakat setempat
(Koeshendrajana, et al., 2007).

Umumnya, responden lebih memilih untuk memberi nilai lebih pada NP kemudian NK sumberdaya danau. Besarnya NP ini mengindikasikan bahwa masyarakat setempat, memiliki harapan yang besar pada sumberdaya danau agar dapat dimanfaatkan bagi anak-cucu di masa mendatang. Sedangkan pada NK sumberdaya danau (khususnya di daerah reservat), perhatian responden tidak terlalu perhatian dengan wilayah reservat yang ada. Bahkan beberapa dari responden mengaku kadang-kadang mereka menangkap ikan di wilayah reservat (di danau Tempe dikenal istilah "Pacco' Balanda"sebagai wilayah reservat).

\subsubsection{Pendugaan WTP nilai keberadaan}

Hasil survei memberikan informasi mengenai persepsi masyarakat terhadap manfaat yang dapat diambil dari keberadaan sumberdaya danau. Persamaan yang digunakan adalah persamaan yang digunakan oleh Yaping, (1999). Sehingga dengan menggunakan menggunakan persamaan ini, akan dijelaskan katerkaitan karakteristik pemanfaat sumberdaya danau dengan nilai WTP tersebut.

Dugaan besaran nilai terhadap keberadaan sumberdaya danau oleh tiap responden yang didapat dari model adalah $\mathrm{Rp}$. 221.903. Rata-rata pendapatan per tahun responden adalah $\mathrm{Rp}$. 25.067.838 dengan lama mengikuti pendidikan rata-rata 6 tahun atau setingkat tamatan SD, dan rata-rata pengalaman usaha 18 tahun. Adapun nilai keberadaan Danau Tempe adalah Rp. 606.905.999.

Berdasarkan data tersebut dihasilkan model pendugaan nilai pemanfaatan berdasarkan nilai keberadaan sumberdaya danau dengan menggunakan pendekatan Yaping, (1999), sebagai berikut :

$$
\operatorname{LnWTP}=11,41+0,19 \frac{1}{n} \sum_{i=1}^{n} \operatorname{Ln} A+0,5 \frac{1}{n} \sum_{i=1}^{n} \operatorname{Ln} E+0,11 \frac{1}{n} \sum_{i=1}^{n} \operatorname{LnXP}-0,06 \frac{1}{n} \sum_{i=1}^{n} \operatorname{LnI}
$$


Standard

Error

Intercept 4,478404515

$\operatorname{Ln} A \quad 1,133284242$

LnE $\quad 0,350155237$

$\operatorname{Ln} X P$

$\operatorname{Ln} I$

0,354762287

0,153842645

$$
t \text { Stat }
$$

$P$-value

2,547636486

0,168869648

1,416374152

0,323897931

$-0,376225018$

0,019174

0,867595

0,172053

0,749378

0.710711
Berdasarkan karakteristik statistik, tiap variabel memberikan karakteristik yang berbeda. Dalam tingkat kepercayaan 0.20, secara keseluruhan variabel memberi pengaruh nyata terhadap WTP nilai keberadaan. Namun secara parsial terlihat bahwa hanya variabel $\mathrm{E}$ (pendidikan) memberi pengaruh nyata terhadap Nilai WTP keberadaan sumberdaya tersebut.

Implikasi dari model tersebut, diketahui bahwa nilai keberadaan sumberdaya danau yang diberikan oleh seorang dari masyarakat setempat (di bawah 13 tahun, belum bekerja, belum punya pengalaman serta tidak berpendidikan) diduga sebesar Rp. 90.160. Preferensi masyarakat di sekitar Kompleks Danau Tempe terhadap sumberdaya Danau akan meningkat seiring dengan meningkatnya usia, pendidikan dan pengalaman masyarakat dalam mengelola sumberdaya tersebut.

Peningkatan pendapatan dari pemanfaatan sumberdaya tersebut akan berdampak menurunnya preferensi masyarakat terhadap nilai keberadaan sumberdaya tersebut.

Model tersebut mengindikasikan bahwa faktor pendidikan lebih dominan dalam memberikan pertambahan nilai terhadap preferensi nilai keberadaan sumberdaya danau. Yakni, setiap peningkatan lama pendidikan 1 tahun akan menambah 0.5 dari nilai WTP (Nilai Keberadaan) sumberdaya danau. Demikian pula pada faktor usia dan pengalaman, tiap bertambahnya usia dan pengalaman satu tahun akan meningkatkan 0.19 dan 0.11 dari nilai keberadaan sumberdaya danau. Sedangkan untuk faktor pendapatan, walaupun relatif kecil namun faktor ini mengurangi nilai keberadaan sumberdaya danau. Faktor pengurangnya adalah 0.06 dari nilai keberadaan sumberdaya danau. Artinya Nilai Keberadaan dari sumberdaya Danau Tempe oleh masyarakat setempet dapat ditingkatkan dengan penyadaran masyarakat melalui program peningkatan pendidikan. Dengan bertambahnya lama pendidikan diharapkan kesadaran masyarakat terhadap arti pentingnya keberadaan sumberdaya danau. Sehingga upaya eksploitasi yang berkelanjutan dapat dilaksanakan serta meningkatnya partisipasi masyarakat dalam memikirkan pemanfaatan sumberdaya danau.

\subsubsection{P e n d u g a a n W T P N i I a i Pelestarian/Keberlangsungan Sumberdaya}

$\mathrm{P}$ e r h i t u n g n $\quad \mathrm{Ni}$ I a i Pelestarian/Keberlangsungan sumberdaya ini menggunakan persamaan yang digunakan oleh Yaping, (1999). Hasilnya berupa model bagai berikut;

$$
\begin{aligned}
& \text { LnWTP }=7,95+0,72 \frac{1}{n} \sum_{i=1}^{n} \operatorname{Ln} A+0,48 \frac{1}{n} \sum_{i=1}^{n} \operatorname{LnE}+ \\
& 0,13 \frac{1}{n} \sum_{i=1}^{n} \operatorname{LnXP}+0,09 \frac{1}{n} \sum_{i=1}^{n} \operatorname{LnI}
\end{aligned}
$$

\begin{tabular}{llcc} 
& \multicolumn{1}{c}{$\begin{array}{c}\text { Standard } \\
\text { Error }\end{array}$} & \multicolumn{1}{c}{$t$ Stat } & $P$-value \\
Intercept & 4,696093699 & 1,69228572 & 0,107829162 \\
LnA & 1,062617041 & 0,68158299 & 0,504178566 \\
LnE & 0,34222031 & 1,41469876 & 0,174223208 \\
LnXP & 0,290173858 & 0,45796048 & 0,652461021 \\
Ln I & 0,167604336 & 0,52960348 & 0,602858444
\end{tabular}

Berdasarkan karakteristik statistik, tiap variabel memberikan karakteristik yang berbeda. Dalam tingkat kepercayaan 0.20, secara keseluruhan variabel memberi pengaruh nyata terhadap pendugaan WTP nilai Pelestarian/Keberlangsungan Sumberdaya. Namun secara parsial terlihat bahwa hanya variabel E (pendidikan) memberi pengaruh nyata terhadap Nilai WTP keberadaan sumberdaya tersebut.

Dugaan besaran terhadap nilai Pelestarian/Keberlangsungan sumberdaya danau oleh tiap responden yang didapat dari 
model adalah Rp. 495.691. Adapun Nilai Pelestarian/Keberlangsungan sumberdaya sungai dan rawa adalah Rp. 1.355.715.328.(Koeshendrajana, et al., 2007).

Karakteristik sosial ekonomi yang tercakup pada perhitungan nilai tersebut seluruhnya adalah positif. Artinya bahwa Nilai Pelestarian dari kegiatan sumberdaya danau yang bertujuan untuk mempertahankan keberlanjutan pemanfaatan sumberdaya danau selalu bertambah seiring dengan bertambahnya usia, tingkat pendidikan, pengalaman dan pendapatan. Positifnya nilai variabel diatas, tidak lepas dari arahan Nilai Pelestarian dalam kuesioner yang mengusulkan besaran uang yang mampu dikeluarkan oleh responden. Dalam hal ini, umumnya responden memilih untuk membayar iuran sebagai bentuk pengorbanan untuk memelihara, pengawasan dan pembentukan reservat. Tentu saja dengan harapan di kemudian hari anak cucu tetap dapat mendapat manfaat dari danau tersebut.

Model tersebut mengindikasikan bahwa faktor usia lebih dominan dalam memberikan pertambahan nilai terhadap preferensi nilai pelestarian sumberdaya danau. Yakni, setiap penambahan usia 1 tahun akan menambah 0,72 dari nilai WTP (Nilai Pelestarian) sumberdaya danau. Demikian pula pada faktor pendidikan dan pengalaman, tiap bertambahnya usia dan pengalaman satu tahun akan meningkatkan 0,48 dan 0,13 dari nilai pelestarian sumberdaya danau. Sedangkan untuk faktor pendapatan, walaupun relatif kecil namun faktor ini menambah nilai pelestarian sumberdaya danau. Faktor ini akan bertambah 0,09 dari nilai pelestarian sumberdaya danau.

\subsection{Total Nilai Bukan Pemanfaatan Sumberdaya Danau Tempe}

Besarnya nilai keberlanjutan dibanding nilai-nilai lainnya dalam perhitungan non use value, mengindikasikan bahwa masyarakat di sekitar Danau Tempe sangat berharap kelestarian sumberdaya danau dapat
Tabel2. Total Nilai Bukan Pemanfaatan Sumberdaya Danau Tempe, 2008

Table 2. Total Non Use Values of the Lake Tempe Resource, 2008

\begin{tabular}{lll}
\hline No. & \multicolumn{1}{c}{ Nilai Bukan } & Nilai/Value \\
& Pemanfaatan/ & (Rp) \\
& \multicolumn{2}{c}{ Non Use Values } \\
\hline 1. & Keberadaan/ \\
& Existence & 606.905 .999 \\
2. & Pelestarian/ Bequest & 1.355 .715 .328 \\
\hline & Total & 1.962 .621 .327 \\
\hline
\end{tabular}

dipertahankan. Dengan keinginan membayar untuk iuran antar sesama pengguna dari danau yang dialokasikan untuk kelestarian sumberdaya sebaiknya menjadi petimbangan dalam pengelolaan sumberdaya berbasis masyarakat. Dengan target yang jelas dan konsistensi dalam upaya pencapaiannya, dapat menjadi modal bagi pengelolaan sumberdaya danau yang berkelanjutan, serta memperhatikan kebutuhan yang bersifat kekinian. Dalam model pun diungkap bahwa faktor dominan yang mampu direkayasa dalam program pengembangan masyarakat adalah peningkatan pendidikan. Meningkatnya faktor ini, diduga akan meningkatkan sebesar 0,48 dari Nilai Pelestarian / Keberlangsungan sumberdaya. Dengan demikian akan tumbuh kesadaran akan pentingnya sustainability dalam pengelolaan dan pemanfaatan sumberdaya.

Data dan hasil analisis menunjukkan bahwa faktor pengalaman responden di danau tempe cukup besar dalam menyumbang nilai terhadap kelestarian sumberdaya. Indikasi yang muncul selanjutnya, masyarakat pasrah terhadap kondisi sumberdaya yang terus memburuk. Anggapan bahwa kondisi danau yang terjadai sekarang adalah "given" dan sulit untuk memperbaikinya. Faktor sedimentasi yang besar hingga menyebabkan pendangkalan dan penurunan kualitas lingkungan juga berdampak kepada pendapatan rata-rata responden. 
Indikasi degradasi sosial ekonomi yang dapat diambil dari penelitian ini adalah pada nilai keberadaan sumberdaya danau. nilai ini menempati urutan terakhir. Nilai Keberadaan sumberdaya danau dalam penelitian ini mengangkat aktivitas yang secara langsung bersinggungan dengan kehidupan sehari-hari masyarakat setempat. Nilai yang didapatkan dari pilihan konversi biaya untuk operasional patroli di lingkungan danau, iuran untuk patroli, atau mengurangi aktivitas pemanfaatan wilayah penangkapan dinilai paling rendah oleh masyarakat setempat. Ini berarti, besarnya kebutuhan kekinian dikaitkan dengan kemampuan sumberdaya danau menyediakan sumberdaya yang dapat dimanfaatkan semakin terdegradasi. Tanpa perlu melakukan patroli di wilayah reservat, ataupun iuran serta mengurangi aktivitas penangkapan, hasil yang didapatkan setiap harinya tetap saja minim.

Peningkatan faktor pendapatan pada Nilai Keberadaan sumberdaya, tidak mengindikasikan meningkatnya preferensi masyarakat terhadap nilai keberadaan sumberdaya danau. Hasil survei terhadap pola pemanfaatan sumberdaya oleh masyarakat setempat, mengindikasikan pemanfaatan danau yang sebatas faktor produksi untuk memenuhi kebutuhan masyarakat. Umumnya masyarakat cenderung memanfaatkan sumberdaya secara maksimal tanpa memperhatikan keberadaan sumberdaya danau. Makin maraknya penggunaan bahan herbisida maupun pestisida untuk kegiatan pertanian di lahan pertanian (tanah koti). Bahan-bahan ini merangsang perkembangan gulma air. Seterusnya gulma ini kemudian dimanfaatkan sebagai alat bantu tangkap ikan. Aktifitas yang saling terkait ini berdampak pada menurunnya kualitas perairan akibat pertumbuhan dan perkembangan gulma air. Selanjutnya pendangkalan tak terhindari lagi, juga tak lepas dari peran dan keberadaan gulma air.

Selain itu, variabel pendapatan yang berdampak negatif terhadap nilai keberadaan tersebut dipengaruhi oleh adanya responden yang berpendapatan besar, namun memberi nilai keberadaan yang relatif kecil. Sehingga mempengaruhi keseluruhan perhitungan WTP. Jika seandainya responden tersebut tidak dimasukkan dalam perhitungan maka berpengaruh positif terhadap nilai keberadaannya. Besarnya pendapatan responden tersebut dikarenakan responden tersebut adalah pemilik modal dan aset usaha (juragan) di lokasi survei. Seperti pada kondisi sosial ekonomi masyarakat pesisir (patronklien) "Punggawa-Sawi" atau "Juragan-ABK", juragan tersebut turut membantu anggota yang masuk dalam sistem usahanya. Sehingga pertimbangan besarnya/kecilnya keinginan mengeluarkan uang untuk nilai keberadaan sumberdaya dipengaruhi oleh posisinya sebagai juragan. Selain itu, besarnya investasi dan biaya operasional yang ditanggung juragan turut mempengaruhi WTP yang diberikan olehnya.

\section{KESIMPULAN DAN IMPLIKASI KEBIJAKAN}

\section{Kesimpulan}

1. Total Nilai Bukan Manfaat Danau Tempe yang didapat dengan menggunakan pendekatan CVM adalah sebesar Rp. 1.962.621.327. Nilai tersebut terdiri dari Nilai Keberadaan sebesar Rp. 606.905.999, dan Nilai Pelestarian/ Keberlangsungan sumberdaya danau sebesar Rp. 1.355.715.328.

2. Nilai bukan manfaat tersebut menggambarkan penilaian masyarakat terhadap kepentingan dan keberlangsungan sumberdaya tersebut.

3. Persepsi masyarakat terhadap sumberdaya masih kurang mencukupi untuk mewujudkan keberlangsungan sumberdaya. Hal ini didorong oleh kondisi ekonomi yang masih menjadi prioritas utama. 


\section{Implikasi Kebijakan}

1. Diperlukan upaya rehabilitasi sumberdaya, mengingat semakin terdegradasinya sumberdaya danau tersebut. Kebutuhan ini direfleksikan oleh besarnya harapan masyarakat pada pelestarian/keberlanjutan sumberdaya. Dibanding dengan nilai keberadaan, besarnya nilai pelestarian/keberlanjutan dapat mengindikasikan bahwa masyarakat sangat menginginkan kondisi sumberdaya yang ada dapat pula dinikmati oleh anak-cucu dikemudian hari.

2. Percepatan pemahaman masyarakat dalam menilai pentingnya keberlangsungan sumberdaya. Hal ini dapat dilakukan melalui peningkatan kualitas pendidikan, sebagai faktor yang dapat meningkatkan kesadaran masyarakat. Diharapkan dengan meningkatnya kesadaran masyarakat dapat pula meningkatkan preferensi masyarakat terhadap nilai sumberdaya.. Sehingga tinjauan sumberdaya sebagai faktor untuk memenuhi kebutuhan tidak sebatas pada hasil manfaat langsung yang dapat diekstrak.

3. Perlunya kegiatan alternatif mata pencaharian yang mampu mengurangi beban lingkungan perairan danau. Hal ini dapat dilakukan dengan memanfaatkan gulma air yang banyak terdapat di Danau Tempe, seperti kompos, kerajinan dan suvenir. Kegiatan ini dapat mengurangi dampak pendangkalan yang salah satunya disebabkan banyaknya gulma air.

\section{DAFTAR PUSTAKA}

Adrianto, L. 2007. Teknik Pengumpulan dan Analisis Data Valuasi Ekonomi Sumberdaya Pesisir dan Lautan: Contingent Valuation Menthod. Dalam Modul Trainning: Teknik Pengumpulan dan Analisis Data Valuasi Ekonomi Sumberdaya Pesisir dan Laut. PKSPLIPB.

Davis, L.S. and K.N. Johnson. 1987. Forest Management. McGraw Hill Book Company. New York.

Dosi, C. 2000. Enviromental Values, Valuation Methods, and Natural Disaster Damage Assesment.

FAO, 2000. Application of Contingent Valuation Method in Developing Countries. FAO Economic and Social Development Papers No 146/200. FAO. Rome.

Grigalunas, T.A anf R. Congar. 1995. Environment Economics for Integrated Coastal Area Menegement: Valuation Methods and Policy Instruments. UNEP Regional Seas Report and Studies No. 164. UNEP.

Koeshendrajana, S., Priyatna, F.N., Muliawan, I., Ramadhan. A., Reswati, A., Triyanti, R., Fakhruddin, A., Kartamihadja, E.S., Purnomo, K., Utomo, A.G. 2007. Laporan Teknis Riset Identifikasi Karakterisasi dan Valuasi Sosial Ekonomi Sumberdaya Kelautan dan Perikanan. BBRSE. BRKP. DKP.

Winpenny, J. T. 1991. Values for the Environment: A Guide to Economic Appraisal, ODI: London.

Yaping, D. 1999. The Value of Improved Water Quality for Recreation in East Lake, Wuhan China. EEPSEA, Singapore. 